\title{
Improved Growth Pattern of Tiger Prawn (TP) Arthropoda in a pond by Analytical Hierarchical Process (AHP)
}

\author{
Adnan Alam Khan*, Syed Asif Ali
}

1 write2adnanalamkhan@gmail.com, adnan.alam@dsu.edu.pk, Sindh Madressatul Islam University, DHA SUFFA University

2 Sindh Madressatul Islam University, Karachi, Pakistan.

* Correspondence: write2adnanalamkhan@gmail.com; Tel.: (+923008234205 WhatsApp)

\begin{abstract}
Artificial intelligence (AI) is a versatile term that is a conclusive remedy to solve the problem using past rational data after deep contemplation using these terms i-e basic statistics, carving data, familiarity with common AI algorithms. Seafood especially tiger prawn export as a business will provide enormous foreign exchange to any country if the farmers overcome the correlated vulnerabilities in prawn farming. This research is elucidating lacking in Tiger prawn (TP) farming like curbing of Oxygen, $\mathrm{pH}$, water temperature, and nutrients, etc. Moreover, hatchery statistics in terms of juveniles will depict this study's clear picture of curbed aquaculture. For normative decisions, the Analytical Hierarchical Process (AHP) is used. The problem which has been faced by local prawn farmers that there is a stagnant TP growth in ponds, the reason is the predominant sensitivity factor in TP. For this reason, they need indemnification of thirteen factors with natural resources to get the plausible results to get calmness in their lives. This study will solely focus on the TP growth model, and the monitoring effect will be established by the Artificial Intelligence algorithm. This study will employ the AHP, 0-1 scaling method, data curation techniques, and ecological statistics. The life of Tiger Prawn (TP) depends upon these factors mainly, a) Physical and b) Chemical parameters. Physical parameters contain environment (E) provided to TP like season (S) and temperature (T) etc. whereas the quality of Ammonia NH3 $(\mathrm{N})$ from fish waste, Oxygen level $(\mathrm{O})$, and water quality hard \& soft $(\mathrm{W})$ lies in chemicals domain. This research will Elucidate the factors which cause conceptual muddles in the aquamarine life of TP, for this reason, Statistical tools will assess the current result, forecast the gap. AHP will analyze the domain inputs, circumspect ramification which will depict visceral factors, later results depict which pond suits the TP. In curtail, these factors will be curbed to improve the growth of TP in a control conditioned environment.
\end{abstract}

Keywords: Artificial Intelligent algorithms, Analytical Hierarchical Process (AHP), Prediction methods, unsupervised learning, and Biological neural networks.

\section{Introduction}

Intelligence means to divide a problem, solve it, learn, and elucidates feedback, whereas Artificial Intelligence (AI) is a coin that incumbent all the aforementioned factors using the software. In short AI relief the human brain from logical drudgery. This research encompassing inadequacies in the pond of $\mathrm{TP}$ and $\mathrm{AI}$ is acting here as a discerning tool that contemplates the real-time facts and transforms the environment into a conducive pond environment. The motive of this research is to highlight logical malleability in allochory and explore the scientific reasons in agamospecies by alee effect. Humans are doing rumpus in alcyonarian life by their agonistic behavior nowadays. Toxic waste is vanishing aragonite and ascanoid at an exponential rate, now researchers are developing artificial reefs inside river delta and sea bed to know Arthropoda and arborescent colony growth pattern. One of the reasons is algal bloom which reduces Oxygen $(\mathrm{O} 2)$ in water, allochronic speciation, change of water $\mathrm{pH}$ by toxic waste, and water temperature. Tiger 
prawn is a famous species which is mostly located at Arabian, Indian, Far East, and Australian peninsula furthermore it's also found in US coasts, etc. Taxonomy of this species is Class: Malacostraca, Order: Decapoda, Family: Penaeidae, crevettes, pénaéïdes, penaeid, shrimps. Genus: Penaeus, Species: Penaeus, monodon [1]. Irrefutable research is carried out in the year 2008 which focuses solely on surpassed tiger prawn catches in their breeding months like July, August and September are 16,174 and the other month's catch rate is 3512 and its ratio is 5:1 which was the actual logical malleability. In other words, environmental effects were not the apparent reason but the abnormal caught was the conclusive reason behind this inadequacy [2]. Carbon is imperative for any sea creature like tiger prawn (TP), the powder of molasses from sugar or sweet potato, bran from rice and cassava is the obvious remedy for the formation of bio-flocs. This study adduces that TP survival rate and water crummiest are capsized by this powder [3]. This study is recapitulating of two main scrupulous factors, first, indemnify the gene-diversity of TP with the rest of the world and the second one is prevalent indigenous environment factors [4]. Tiger prawn alias grass prawn, the primitive reason is its food cycle and it is solely based on seaweed which is a grass in the sea, enriched with nutrients, vitamins, lipid mobilization which improves absorption [5]. The scrupulous research article that succinct that TP life cycle will be disturbed if scanty in its feed like nutrients, feed time table, TP body growth pattern, and water temperature [6]. TP can live long if the following factors are maintained like curbing catches, natural incumbent morality, and the vigorous environment that suits TP [7]. Thomas Robert Malthus had proposed a single species population model that succinct food exponential growth rate and specie growth pattern at a point where these two lines intersect each other means species will grow with the same rate but food supply is lagging behind the supply [8]. This colossal research is encompassing TP statistics like the average number of eggs by pair, moreover eggs classification like Type A, Type B, Type C, and Type D, etc. in which Type A average hatch rate is 58\% [9]. This study is the assimilation of two frazzle factors like fecundity of TP in-terms of its weight and production of quality larva or Nauplius. The vindicated solution is genetics savvy [10]. This study impugned the area provided to TP which must be 0.37 ha for production of $28,880 \mathrm{Kg}$ as a breakeven, another questioned this study raised in other factors are not playing significant effect on TP life-like quality feed, chemicals, water treatment in terms of oxygen and $\mathrm{pH}[11]$. This study narrative is incumbent which cite damages of reefs due to unscrupulous industrial waste and its slow rate of recovery of these reefs and its visceral on others [12]. This research aims to provide indemnify normative incumbent conclusive results based on Logistic and Von Bertalanffy prey populations. Recapitulate of this research is not correlating to the factors prey and population [13]. This study signifies that the use of chlorophyll or higher natural products as periphyton has an inclusive impact on TP growth [14].

The researchers had eclectic TP to know the juxtaposition of male and female TP. Salubrious female TP growth was spur initially in-terms of dimorphism and the main reason which elucidates was fattening rate in female TP which is more predominant than of male $\mathrm{TP}$, in contrast, female TP has shorter life span than male TP. In curtail statistics succinct depicts there is a negative correlation between them initially [15]. The fish food cycle is incomplete without juvenile or adult prawns that is imperative for any fish cycle. Statistics depict the survival rate of larvae is $30 \%<\mathrm{X}$, juvenile TP $25 \%<\mathrm{X}$, and adult TP $10 \%<\mathrm{X}[16]$. The succinct, irrefutable and most rational growth model of any species can be concluded by AHP, which elucidates by access all correlated factors in-terms of time, indemnify, and adjudicate the imperative decision in-terms of maths and statistics with the tolerance level of 5\%[17]. AHP indemnifies the imperative decision by taking into the accounts different inputs that are correlated with $\mathrm{TP}$, the ramification might be highly intermittent if it is scanty in domain inputs. For primitive decision the panegyric recital must be complete, this study has semantic research and contemplated facts are divulge encompassing $\mathrm{Bu}-$ shehr Province of Iran [18]. Different companies are researching prawns by taking into 
account AI algorithm that will be integrated with the data science model to get the optimized growth pattern of the prawn family from the inimical environment, few examples are observed technology, eFishery, and umitron cell, etc.[19]. Assimilation of oxygen in pond water vindicated the stunning growth rate in the prawn family. This divulges the water quality with limited inimical germs in the pond, which capsizes the growth pattern using AI [20]. Deep learning is comprised of unknown hidden layers for decision making based on weights, the most frazzle of deep learning is carving data set which is used for domain input. This research inculcate by analysis, computer vision, carving input data, algorithm and correlated performance, in contrast for optimum vindicated results require large data set [21]. This stunning research whose narrative is closely related to Power Heuristics $(\mathrm{PH})$, an Evolutionary Algorithm (EA), that hinders grievous mistakes in prawn feeding plan and provides the results of the contemplation to the users [22]. This study provides an in-depth analysis of Tiger Prawn (TP) growth pattern factors, curbing, and contemplation using Deep learning. Domain input for this study is comprised of thirteen vigorous factors like Physical parameters, Environment, Season, temperature, chemical, water both soft \& hard, ammonia, nutrients food, oxygenated water, and other correlated factors, etc. This study has examined that food type A, B, C, and D also, oxygenated water, controlled water temperature, curbing $\mathrm{pH}$, etc. will capsize the TP growth pattern.

\section{Related Work}

Numerous factors affect aquamarine life, especially prawns, lobsters, and shrimps (PLS). TP birth rate and death rate model using Malthusian population growth pattern i-e $\mathrm{P}(\mathrm{t})=$ $P_{0 .} e^{\lambda_{t}}$, here $\lambda$ depicts essential parameters to TP like food, environment, and nutrients, etc. For a better in-depth explanation, real-time data will be used by this study. Begin with female TP quality eggs which are almost 300,000 out of which only $58 \%$ eggs will hatch. The TP farmer can produce ( 1500 Kilogram per hectare) in which average Female TP weight will be 200gram to 320 gram, and Male TP weight would be smaller than the female which is about 100 gram to 170 gram 0.5 million 5 Lac to 0.75 million or 7 Lac $50 \mathrm{~K}$ of Eggs, hatching after $12 \mathrm{Hrs}$ to $15 \mathrm{Hrs}$, the suitable saltwater temp would be $18^{\circ} \mathrm{C}$ to- $34.5^{\circ} \mathrm{C}$. $1500^{*} 1000=1500,000$ grams $/ 300=5000$ Tiger prawn in Ha. Now, this study put 5000 juvenile of TP in a pound and related calculations are as follows to know the time in which farmers will get 100,000 TP. a) Female TP lays on average 300,000 eggs, b) Half of TP are female's means 2500 c) Successful hatch rate in A category eggs is $58 \%$ d) TP life cycle is of 120 days or 4 months. If investors want 100,000 TP so what would be the growth rate (K).

TP life cycle is 4 months $=(\ln 2) / \mathrm{K}$

So, $\mathrm{K}=\ln (2 / 4)=0.173$

Or $100,000=5000 \cdot \mathrm{e}^{(0.173 t)}$.

Or $\quad 20=\mathrm{e}^{(0.173 \mathrm{t})}$

Or $\ln (20)=0.173 t$

Means Time $(t)=17.31 \cong 18$ months. Our calculation depicts our farmer can grow 100,000 prawns out of 5000 prawns in 18 month time period if it is eclectic the following salubrious 
colossal facts to get capsize colossal results. The bitter truth encompassing TP is $42 \%$ of eggs lost means less TP juvenile, to overcome this inadequacy the farmer must accept irrefutable facts. For Mathematical contemplation differentiate the population of TP w-r-t time in years. For juxtaposition of birth and death model this research employed TP Birth \& death model: $\frac{d p}{d t}=P . g(r)$. Malthus depicts in his model that there is a strong correlation between population growth and food supplies. In other words, the food supply will lag to the population growth. Furthermore it ratio will be "+" or "-"based on food supplies for the decline in the population.

Here this study chose a symbol " $\mathrm{r}$ " to inculcate the difference of birthrate and death rate of TP so,

$\mathrm{r}=$ birth-death

According to Malthus model $\frac{d P}{d t}=P_{0} \cdot e^{\lambda t} \cdot \lambda \ldots .(2)$

Initial population means zero eggs so, $\mathrm{P}(0)=\mathrm{P}_{0}$, Comparing eq 1 and eq 2

r. $P_{0}=P_{0} . e^{(\lambda t)} \cdot \lambda \quad$ Eliminating $P_{0}$ from both sides

$r=e^{(\lambda t)} \cdot \lambda \quad$ but $r=(b-d)$

$b-d=e(\lambda t) \cdot \lambda$

$b=e(\lambda t) \cdot \lambda+d \quad$ ignoring death rate

$\frac{d b}{d t}=e^{\lambda t} \cdot \lambda \cdot \lambda+0$

$\frac{d b}{d t}=e^{\lambda t} \cdot \lambda^{2}$

The aforementioned equation depicts that the proposed mathematical model for TP birth rate is colossal, this adduces that fecundity of tiger prawn has an incumbent relationship with " $\lambda$ "means Food (F), Environment (E), and Nutrients (N). For the resurrection of TP, this study replaces " $\lambda$ "with EFN succinct contemplation.

So, $\frac{d B}{d t}=e^{(\mathrm{F}+\mathrm{E}+\mathrm{N}) \mathrm{t}} \cdot(\mathrm{F}+\mathrm{E}+\mathrm{N})^{2}$

Here this model depicts the primitiveness of TP birth which is twice of food supplies to the TP. In other words, the debase impurities in the oceans are the apparent reason which is damaging salubrious TP aquaculture. This study has conducted in-depth contemplated pertinent research that will redeem the debacle shores. 
Table 1. Conclusive factors for Tiger Prawn rehabilitation

\begin{tabular}{cc}
\hline Conclusive Factors & Symbol \\
\hline Physical Parameters & $\mathrm{PP}$ \\
Environment & $\mathrm{E}$ \\
Temperature & $\mathrm{T}$ \\
Chemical properties & $\mathrm{C}$ \\
Water & $\mathrm{HW}$ \\
Hard water (High mineral) & $\mathrm{SW}$ \\
Soft water(low mineral) & $\mathrm{A}$ \\
Ammonia (Fish poo) & $\mathrm{F}$ \\
Food & $\mathrm{N}$ \\
Nitrate (converted NH3) & $\mathrm{O}$ \\
Oxygen & $\mathrm{X}$ \\
Miscellaneous Factors & $\mathrm{S}$ \\
\hline
\end{tabular}

TP growth model is directly correlated with the aforementioned thirteen factors. The first important factor is a physical parameter that covers temperature of water, environment and season, etc., The following mathematical model glorifies oblivious primitive factors that incumbent to the growth model of TP. Further, this study will transform frazzle scanty parameters whose improvement and assimilation in the form of a digital circuit is presented in this research. These parameters will be used to mesmerize and recapitulated results after AHP in-depth contemplation. Mathematical derivation is as follows:

Chemical: $\mathrm{C} \rightarrow(\mathrm{N} \wedge \mathrm{F})$, Water: $\mathrm{W} \rightarrow(\mathrm{PH} \wedge \mathrm{O})$, Environment: $\mathrm{E} \rightarrow(\mathrm{S} \wedge \mathrm{T})$

$[\mathrm{C} \rightarrow(\mathrm{N} \wedge \mathrm{F})] \wedge[\mathrm{W} \rightarrow(\mathrm{PH} \wedge \mathrm{O})] \wedge[\mathrm{E} \rightarrow(\mathrm{S} \wedge \mathrm{T})] \rightarrow(\mathrm{X} \vee \mathrm{PP})$

$[\neg \mathrm{C} v(\mathrm{~N} \wedge \mathrm{F})] \wedge[\neg \mathrm{W} v(\mathrm{PH} \wedge \mathrm{O})] \wedge[\neg \mathrm{Ev}(\mathrm{S} \wedge \mathrm{T})] \rightarrow(\mathrm{X} v \mathrm{PP})$

$[(\neg \mathrm{C} v \mathrm{~N}) \wedge(\neg \mathrm{C} v \mathrm{~F})] \wedge[(\neg \mathrm{W} v \mathrm{PH}) \wedge(\neg \mathrm{W} v \mathrm{O})] \wedge[(\neg \mathrm{E} v \mathrm{~S})] \wedge(\neg \mathrm{E} v \mathrm{~T})] \rightarrow(\mathrm{X} v \mathrm{PP})$

$[(\mathrm{N} \wedge \mathrm{F})] \wedge(\mathrm{PH} \wedge \mathrm{O})] \wedge[(\mathrm{S} \wedge \mathrm{T})] \rightarrow(\mathrm{X} \vee \mathrm{PP})$

$[\mathrm{N} \wedge \mathrm{F} \wedge \mathrm{PH} \wedge \mathrm{O} \wedge \mathrm{S} \wedge \mathrm{T}] \rightarrow(\mathrm{X} \vee \mathrm{PP})$

$[\mathrm{N} \wedge \mathrm{F} \wedge \mathrm{PH} \wedge \mathrm{O} \wedge \mathrm{S} \wedge \mathrm{T}] \wedge \mathrm{X} \rightarrow(\mathrm{PP})$

$(\mathrm{N} \wedge \mathrm{F} \wedge \mathrm{PH} \wedge \mathrm{O} \wedge \mathrm{S} \wedge \mathrm{T} \wedge \mathrm{X}) \rightarrow(\mathrm{PP})$

Water Temperature:

$\mathrm{H}=$ Water temperature is HOT

$\mathrm{C}=$ Water temperature is COLD

$\mathrm{M}=$ Water temperature is MODERATE

$\mathrm{A}=$ Water Cooler is $\mathrm{ON}$ 
$\mathrm{G}=$ Water Geyser is $\mathrm{ON}$

$[(\mathrm{H} \rightarrow \mathrm{A}) \wedge(\mathrm{C} \rightarrow \mathrm{G})] \wedge[\neg(\mathrm{H} \vee \mathrm{C}) \rightarrow \mathrm{M}] \rightarrow[\neg(\mathrm{A} \vee \mathrm{G}) \rightarrow \mathrm{M}]$

$(\neg \mathrm{H} v \mathrm{~A}) \wedge(\neg \mathrm{C}$ v G) $\wedge[(\neg \mathrm{H} \wedge \neg \mathrm{C}) \rightarrow \mathrm{M}]$

$(\neg \mathrm{H}$ v A $) \wedge(\neg \mathrm{C} v \mathrm{G}) \wedge[\neg(\neg \mathrm{H} \wedge \neg \mathrm{C}) \mathrm{v} \mathrm{M}]$

$(\neg \mathrm{H} v \mathrm{~A}) \wedge(\neg \mathrm{C} v \mathrm{G}) \wedge[\mathrm{H} \vee \mathrm{C} v \mathrm{M}]$

$(\neg \mathrm{H} v \mathrm{~A} \wedge \neg \mathrm{C}$ $\mathrm{G} \wedge \mathrm{H}$ v C v M $) \rightarrow[\neg(\mathrm{A} v \mathrm{G}) \rightarrow \mathrm{M}]$

Water $\mathrm{pH}$ (Hard or Soft):

HW= Hard water

SW=Soft water

MW=Moderate water

$\mathrm{SC}=$ Chemical sensor

$[\mathrm{SC} \rightarrow(\mathrm{HW} \rightarrow \mathrm{CH})] \rightarrow \mathrm{MW}$

$[\mathrm{SC} \rightarrow(\neg \mathrm{HW}$ v CH$) \rightarrow \mathrm{MW}$

$[\neg \mathrm{SC}$ v $(\neg \mathrm{HW}$ v CH$)] \rightarrow \mathrm{MW}$

$[(\neg \mathrm{SC} v \neg \mathrm{HW}) \mathrm{v}(\neg \mathrm{SC}$ v CH$)] \rightarrow \mathrm{MW}$

$[\neg(\mathrm{SC}$ v HW $)$ v $(\mathrm{SC} \rightarrow \mathrm{CH})] \rightarrow \mathrm{MW}$

Electronic circuits are derived from the aforementioned mathematical equations derived for $\mathrm{pH}$ sensors and water control sensors. Furthermore, these circuits will link with the actuator too to get the stable water temperature and $\mathrm{pH}$. Name of the sensors are a) Liquid PH0-14 Value Detect Sensor Module + PH Electrode Probe BNC for Arduino G b) 10pcs Waterproof NTC 10k $\pm 1 \% 3470$ Temperature Temp Sensor Probe. 
A.Water temperature controller.

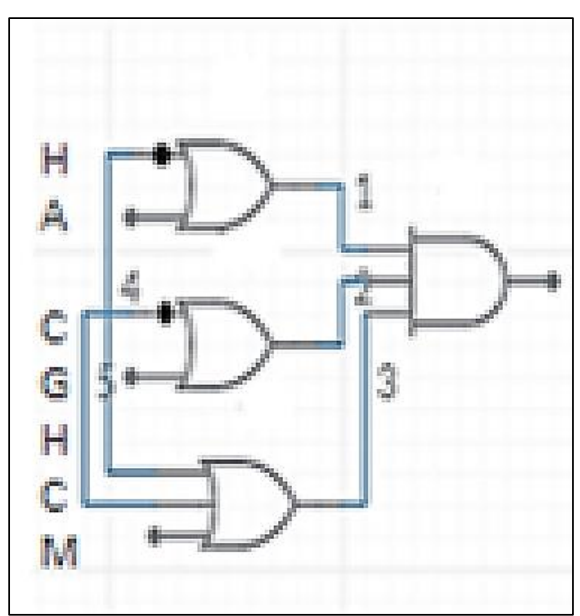

B. Water $\mathrm{pH}$.

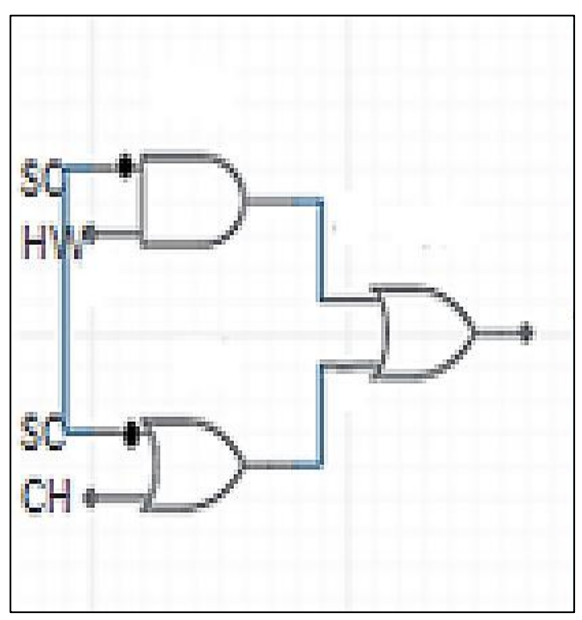

Figure 1. This is a figure of two electronic circuits made for rehabilitation of aquamarine life especially Tiger Prawn (TP);(a) Description of the first circuit is for water temperature controller in other words it maintains water temperature hot or cold based on input domain. ; (b) Description of the second circuit is for pure Hydrogen to get the most conducive water to enhance the TP growth.

Another important aspect for the inclination of TP growth is the availability of food supplies. Our proposed model succinctly that food supply is correlated with the salubrity of TP. For this reason, this study employs various diets which suits TP juvenile. The following table depicts different diets from egg to adult tiger prawns. For this reason, this study has classified diets into five different categories i-e A, B, C, D, and E. These diets are divided as per their age groups which begins from day 1 to day 10,10 to 20,20 to 30,30 to 40,40 to 50, 50 to 60,60 to 70,70 to 80,80 to 90,90 to 100,100 to 110 , and 110 to 120 .

\begin{tabular}{|c|c|c|c|c|c|c|c|c|}
\hline & & & & & Ber $\mathrm{F}$ & Draw & D Di & \\
\hline Days & $\begin{array}{c}\text { Welght In } \\
\text { gens }\end{array}$ & $\begin{array}{l}\text { Growth } \\
\text { Rate }\end{array}$ & Interval & A & B & c & D & E \\
\hline 0.9 & 0 & 0 & 0 & & & & & $\mathrm{x}$ \\
\hline 10 & 1 & 1 & 10 & & & & & $x$ \\
\hline 20 & 4.7 & 3.7 & 10 & & & & & $x$ \\
\hline 30 & 6.8 & 2.1 & 10 & & & $x$ & & $x$ \\
\hline 40 & 14.5 & 7.7 & 10 & & & $x$ & & $x$ \\
\hline 50 & 18.9 & 4.4 & 10 & $\mathrm{x}$ & & $x$ & $x$ & $x$ \\
\hline 60 & 24,1 & 5.2 & 10 & \begin{tabular}{|l|}
$x$ \\
\end{tabular} & & $x$ & $x$ & $x$ \\
\hline 70 & 33,2 & 9,1 & 10 & $x$ & $x$ & $x$ & $x$ & $x$ \\
\hline 80 & 43 & 9,8 & 10 & $x$ & $x$ & $x$ & $x$ & $x$ \\
\hline 90 & 55.6 & 12.6 & 10 & $x$ & $x$ & $x$ & $x$ & $x$ \\
\hline 100 & 62.8 & 7.2 & 10 & $x$ & $x$ & $x$ & $x$ & $x$ \\
\hline 110 & 72.2 & 9,4 & 10 & $x$ & $x$ & $x$ & $x$ & $x$ \\
\hline 120 & 94.1 & 21.9 & 10 & $x$ & $x$ & $x$ & $x$ & $x$ \\
\hline & $k=$ & 7,84 & 120 & & & & & \\
\hline Aabolle & ed Mollusear & iflesh & & & & & & \\
\hline Befrest & h Mollusean & Flesh & & & & & & \\
\hline Cofrest & hollusenn & Floshtwh & ent, rite, mu & ustar & 80 & prav & $w h h$ & \\
\hline Dewher & at,rice,musta & Ird oil, , & in hee & & & & & \\
\hline EnNo st & upplements & & & & & & & \\
\hline
\end{tabular}

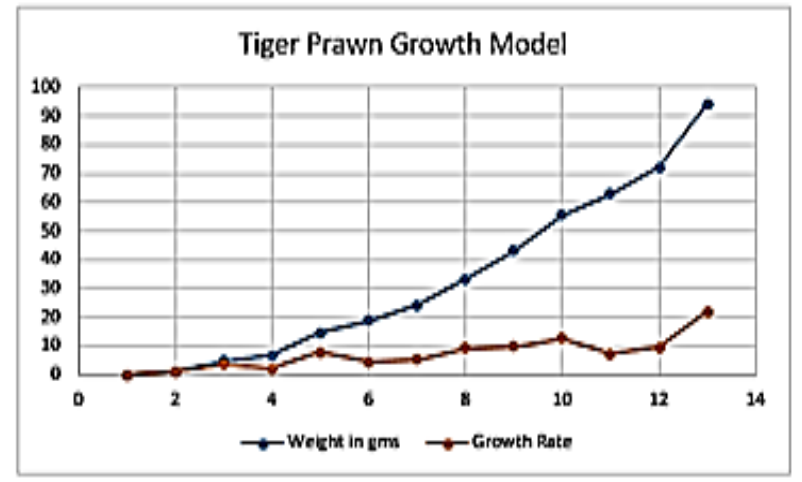

Figure 2. This figure elaborates a standard diet plan for TP in terms of their growth rate \& weight.

For an autonomous decision this study eclectic conducive inputs through various sensors to get rational results, the directions from $\mathrm{AI}$ software is succinct to the farmers about TP ponds hygiene. The proposed model decision adopts AHP that correlates and establishes optimum solution which provides in-depth analysis to users about $\mathrm{pH}$, food, chemicals, and temperature, this study exhibits a clear path to the non-technical farmers, which is 
the way of prosperity. The proposed system is famous for its normative decision, this research is using AHP which adopts fuzzy logic for imperative decisions by the juxtaposition of input variables. Here domain inputs are $\mathrm{pH}$, Nutrients like $\mathrm{Ca}^{++}$and $\mathrm{Mg}^{++}$, Chemicals for softness and hardness of water, dissolved solids in water, water temperature, and fish residues, in general, its Ammonia. Further selection criteria will be adopted from 1 to 11, choose odd numbers only, later combining these inputs pairwise, which will depict the significance of variables which will lead to consistency index, below 10 is accurate. Moreover, the AHP will provide a rating in which you will know which pond environment is conducive. The upcoming tables provide analysis with the help of AHP, which is contemplating the facts of four TP ponds with different values.

Table 2. Intensities of importance as an input in AHP in four different Tiger prawn ponds

\begin{tabular}{|c|c|c|c|c|c|c|}
\hline $\begin{array}{l}\text { Intensities of } \\
\text { Importance }\end{array}$ & Criteria 1 & 1 Criteria 3 & Criteria 5 & Criteria 7 & Criteria 9 & Criteria 11 \\
\hline $\mathrm{pH}$ & $5-5.9$ & $6-6.9$ & $7-7.9$ & $8-8.9$ & $9-9.9$ & $10-10.9$ \\
\hline $\begin{array}{l}\text { Chemicals } \\
\mathrm{Ca}^{++} / \mathrm{Mg}^{++}\end{array}$ & $4-4.9$ & $5-5.9$ & $6-6.9$ & $7-7.9$ & $8-8.9$ & $9-9.9$ \\
\hline $\begin{array}{l}\text { Chemicals for } \\
\text { water Soft- } \\
\text { ness/Hardness }\end{array}$ & $0-0.9$ & $1-1.9$ & $2-2.9$ & $3-3.9$ & $4-4.9$ & $5-5.9$ \\
\hline $\begin{array}{l}\text { Solids in Water } \\
\text { Environ- }\end{array}$ & $100-129$ & $130-159$ & $160-199$ & $200-229$ & $230-259$ & $260-290$ \\
\hline $\begin{array}{c}\text { ment/Temp/Sea- } \\
\text { son } \mathrm{C}^{0}\end{array}$ & $21-21.9$ & $22-22.9$ & $23-23.9$ & $24-24.9$ & $25-25.9$ & $26-26.9$ \\
\hline $\begin{array}{c}\text { Fishes wastes } \\
/ \mathrm{NH}_{3}\end{array}$ & $50-69$ & $70-89$ & 90-109 & $110-129$ & $130-159$ & $160-190$ \\
\hline
\end{tabular}

The aforementioned tables depict intensities for TP ponds, the selection of inputs is performed by AHP which is an AI decision-maker to get the salubrious environment.

Table 3. Four ponds Intensities of importance in AHP for formulation.

\begin{tabular}{|c|c|c|c|c|c|c|}
\hline $\begin{array}{l}\text { Intensities of } \\
\text { Importance }\end{array}$ & $\mathrm{pH}$ & $\begin{array}{c}\text { Chemi- } \\
\text { cals }\left(\mathrm{Ca}^{++} /\right. \\
\left.\mathrm{Mg}^{++}\right)\end{array}$ & $\begin{array}{c}\text { Chemicals } \\
\text { Soft/Hard } \\
\text { water }\end{array}$ & $\begin{array}{l}\text { Solids in } \\
\text { water }\end{array}$ & $\begin{array}{c}\text { Water } \\
\text { Temp/Sea- } \\
\text { son/Environ- } \\
\text { ment } \\
\end{array}$ & $\begin{array}{c}\text { Fish } \\
\text { wastes/Am- } \\
\text { monia }\end{array}$ \\
\hline $\mathrm{pH}$ & 1.000 & 3.000 & 3.000 & 3.000 & 3.000 & 7.000 \\
\hline $\begin{array}{l}\text { Chemicals } \\
\mathrm{Ca}^{++} / \mathrm{Mg}^{++}\end{array}$ & 0.333 & 1.000 & 0.200 & 3.030 & 0.333 & 0.333 \\
\hline $\begin{array}{l}\text { Chemicals for } \\
\text { water Soft- } \\
\text { ness/Hardness }\end{array}$ & 3.000 & 5.000 & 1.000 & 7.008 & 3.003 & 3.003 \\
\hline $\begin{array}{l}\text { Solids in Water } \\
\text { Environ- }\end{array}$ & 0.200 & 0.330 & 0.143 & 1.000 & 0.333 & 0.333 \\
\hline $\begin{array}{c}\text { ment/Temp/Sea- } \\
\text { son } \mathrm{C}^{0}\end{array}$ & 0.330 & 3.000 & 0.333 & 3.000 & 1.000 & 1.000 \\
\hline $\begin{array}{c}\text { Fishes wastes } \\
\qquad / \mathrm{NH}_{3}\end{array}$ & 1.000 & 3.000 & 0.333 & 3.000 & 1.000 & 1.000 \\
\hline SUM & 5.863 & 15.330 & 5.009 & 20.038 & 8.670 & 12.670 \\
\hline
\end{tabular}


Table 4. Normalization of various nominalize inputs into numerical inputs for AHP formulation.

\begin{tabular}{|c|c|c|c|c|c|c|c|}
\hline $\begin{array}{l}\text { Intensities of } \\
\text { Importance }\end{array}$ & $\mathrm{pH}$ & $\begin{array}{l}\text { Chemi- } \\
\text { cals }\left(\mathrm{Ca}^{++}\right. \\
\left./ \mathrm{Mg}^{++}\right)\end{array}$ & $\begin{array}{l}\text { Chemi- } \\
\text { cals } \\
\text { Soft/Har } \\
\text { d water }\end{array}$ & $\begin{array}{c}\text { Solids } \\
\text { in water }\end{array}$ & $\begin{array}{c}\text { Water } \\
\text { Temp/Sea- } \\
\text { son/Envi- } \\
\text { ronment }\end{array}$ & $\begin{array}{c}\text { Fish } \\
\text { wastes/A } \\
\text { mmonia }\end{array}$ & $\begin{array}{c}\text { Weight } \\
\text { s }\end{array}$ \\
\hline $\mathrm{pH}$ & 0.171 & 0.196 & 0.599 & 0.150 & 0.346 & 0.553 & 0.336 \\
\hline $\begin{array}{l}\text { Chemicals } \\
\mathrm{Ca}^{++} / \mathrm{Mg}^{++}\end{array}$ & 0.057 & 0.065 & 0.040 & 0.151 & 0.038 & 0.026 & 0.063 \\
\hline $\begin{array}{l}\text { Chemicals for } \\
\text { water Soft- } \\
\text { ness/Hardness }\end{array}$ & 0.512 & 0.326 & 0.200 & 0.350 & 0.346 & 0.237 & 0.328 \\
\hline $\begin{array}{l}\text { Solids in Water } \\
\text { Environ- }\end{array}$ & 0.034 & 0.022 & 0.028 & 0.050 & 0.038 & 0.026 & 0.033 \\
\hline $\begin{array}{c}\text { ment } / \text { Temp/Sea- } \\
\text { son } C^{0}\end{array}$ & 0.056 & 0.196 & 0.066 & 0.150 & 0.115 & 0.079 & 0.110 \\
\hline $\begin{array}{c}\text { Fishes wastes } \\
\qquad / \mathrm{NH}_{3}\end{array}$ & 0.171 & 0.196 & 0.066 & 0.150 & 0.115 & 0.079 & 0.129 \\
\hline CHECKSUM & 0.739 & 0.587 & 0.839 & 0.651 & 0.731 & 0.816 & 1.000 \\
\hline
\end{tabular}

Table 5. Normalized attributes Matrix from four TP ponds after AHP for formulation.

\begin{tabular}{|c|c|c|c|c|c|c|}
\hline $\begin{array}{l}\text { Vindicated } \\
\text { choices }\end{array}$ & $\mathrm{pH}$ & $\begin{array}{l}\text { Chemi- } \\
\text { cals }\left(\mathrm{Ca}^{++} /\right. \\
\left.\mathrm{Mg}^{++}\right)\end{array}$ & $\begin{array}{c}\text { Chemicals } \\
\text { Soft/Hard } \\
\text { water }\end{array}$ & $\begin{array}{l}\text { Solids in } \\
\text { water }\end{array}$ & $\begin{array}{c}\text { Water } \\
\text { Temp/Sea- } \\
\text { son/Environ- } \\
\text { ment }\end{array}$ & $\begin{array}{c}\text { Fish } \\
\text { wastes/Am- } \\
\text { monia }\end{array}$ \\
\hline Criteria "A" & 0.28169 & 0.25 & 0.100 & 0.3636 & 0.3030 & 0.2133 \\
\hline Criteria “B” & 0.225352 & 0.2 & 0.400 & 0.2727 & 0.2121 & 0.2389 \\
\hline Criteria "C" & 0.211268 & 0.216667 & 0.300 & 0.2727 & 0.3030 & 0.2489 \\
\hline Criteria “D” & 0.28169 & 0.33333 & 0.200 & 0.0909 & 0.1818 & 0.2987 \\
\hline Miscellaneous & 0.00 & 0.00 & 0.00 & 0.00 & 0.00 & 0.00 \\
\hline SUM & 1.000 & 1.000 & 1.000 & 1.000 & 1.000 & 1.000 \\
\hline
\end{tabular}

Table 6. Product of Normalized attributes Matrix and weights to get recommended TP pond

\begin{tabular}{|c|c|c|c|c|}
\hline $\begin{array}{l}\text { Vindicated } \\
\text { choices }\end{array}$ & Weights & Criteria & Pond & $\begin{array}{c}\text { Recommended } \\
\text { Pond }\end{array}$ \\
\hline $\mathrm{pH}$ & 0.336 & 0.216 & A & \\
\hline $\begin{array}{l}\text { Chemicals } \\
\mathrm{Ca}^{++} / \mathrm{Mg}^{++}\end{array}$ & 0.063 & 0.283 & B & $\begin{array}{l}\text { Recommended } \\
\text { Pond }\end{array}$ \\
\hline $\begin{array}{l}\text { Chemicals for } \\
\text { water Soft- } \\
\text { ness/Hardness }\end{array}$ & 0.328 & 0.258 & C & \\
\hline $\begin{array}{l}\text { Solids in Water } \\
\text { Environ- }\end{array}$ & 0.033 & 0.243 & $\mathrm{D}$ & \\
\hline $\begin{array}{c}\text { ment/Temp/Sea- } \\
\text { son } \mathrm{C}^{0}\end{array}$ & 0.110 & 0.000 & None & \\
\hline $\begin{array}{c}\text { Fish waste/ } \\
\text { Ammonia }\end{array}$ & 0.129 & 0.000 & None & \\
\hline
\end{tabular}

Table 6 provides an in-depth analysis of all four ponds and recommended pond " $\mathrm{B}$ " whose statistics meet with requirements. The AHP recommends it a w-r-t highest numeric value which is 0.283 . The aforementioned table 6 also depicts four ponds of different criteria like $\mathrm{pH}$, nutrients or chemicals, soft \& hard water, temperature, and fish wastes, etc. 
The colossal and fecund results are divulged by including eclectic fields to get the irrefutable outcome. This is a way to get effective growth management (EGM) for Tiger Prawn (TP).

\section{Results and Discussion}

This research is establishing a bridge between aquamarine sciences and artificial Intelligence for the betterment of mankind. For this reason this study has solely focused on natural parameters that susceptible by tiger prawn in real world is $\mathrm{pH}$ level, nutrients which includes fish's residues, chemicals like ammonia, Calcium, and Magnesium. Further more water temperature, and softness and hardness of water. Lastly impact of environment is the core palate for Tiger Prawn (TP) life cycle. This study has developed a model that employed AHP as a diametric decision maker that validates domain inputs in four TP ponds, if there is any discrepancy or inadequacy, the system will raised an alert user to remove crummiest in the pond or to add required chemicals as per natural demand of TP. This is embellishing of pond with respect to colossal recommendation of AHP contemplated decision. Aforementioned table 6 depicts pond " $\mathrm{B}$ " has adopted natural requirements of TP and developed a conducive environment that suits the TP in all means. For this reason this study recommends the proposed system to the farmers of TP.

\section{Conclusions}

The plethoric study is carried out in this study that recapitulates. The curbing of Tiger Prawn TP growth statistics will helps farmers to decide the most suitable domain using AHP. The study indicated that prudent measures can't take place by humans but sensor connected to AHP program can easily perform the contemplation through strict curbing in brevity. Results are available for consideration provided electronics circuits, algorithm, and AHP output which has proven the authenticity of this research. 
Acknowledgments: This study was carried out by the Department of Artificial Intelligence researcher Mr.Adnan Alam Khan and this research is solely supported by Prof.Dr.Syed Asif Ali, a well-known researcher and intellectual, whose appropriate guidance makes this Insurmountable research effective growth management (EGM) possible. Lastly, All-mighty Allah and Our Prophet Muhammad SAWW gave me such knowledge to solve this scanty.

\section{References}

1. “Kiel, J. 2013. 'Penaeus monodon' (On-line), Animal Diversity Web. Accessed January 30, 2021.” .

2. N. Niamaimandi, A. Aziz, D. Siti Khalijah, S. Che Roos, and B. Kiabi, "Reproductive biology of the green tiger prawn (Penaeus semisulcatus) in coastal waters of Bushehr, Persian Gulf," ICES J. Mar. Sci., vol. 65, no. 9, pp. 1593-1599, Dec. 2008, doi: 10.1093/icesjms/fsn172.

3. T. Ngoc Hai, “Nursery of the Black Tiger Shrimp Penaeus Monodon Postlarvae in a Biofloc System with Different Carbon Sources," Oceanogr. Fish. Open Access J., vol. 11, no. 5, Feb. 2020, doi: 10.19080/OFOAJ.2020.11.555821.

4. N. T. T. Vu et al., "Fine-scale population structure and evidence for local adaptation in Australian giant black tiger shrimp (Penaeus monodon) using SNP analysis," BMC Genomics, vol. 21, no. 1, p. 669, Dec. 2020, doi: 10.1186/s12864-020-07084$\mathrm{X}$.

5. I. Tsutsui, P. Kanjanaworakul, P. Srisapoome, D. Aue-umneoy, and K. Hamano, “Growth of giant tiger prawn, Penaeus monodon Fabricius, under co-culture with a discarded filamentous seaweed, Chaetomorpha ligustica (Kützing) Kützing, at an aquarium-scale," Aquac. Int., vol. 18, no. 4, pp. 545-553, Jun. 2010, doi: 10.1007/s10499-009-9274-2.

6. A. K. Mishra, M. Verdegem, and A. van Dam, “A Dynamic Simulation Model for Growth of Penaeid shrimps,” p. 23.

7. N. Niamaimandi, A. B. Arshad, S. K. Daud, R. C. Saed, and B. Kiabi, "Population dynamic of green tiger prawn, Penaeus semisulcatus (De Haan) in Bushehr coastal waters, Persian Gulf," Fish. Res., vol. 86, no. 2-3, pp. 105-112, Sep. 2007, doi: 10.1016/j.fishres.2007.05.007.

8. H. Mondol, U. Mallick, and Md. Biswas, “Mathematical modeling and predicting the current trends of human population growth in Bangladesh," Model. Meas. Control D, vol. 39, no. 1, pp. 1-7, Dec. 2018, doi: 10.18280/mmc_d.390101.

9. “Carreon-Lagoc, Julia. 'Fecundity and egg quality of tiger prawn.' Aqua Farm News 7, no. 1 (1989): 8-9.” .

10. S. Ren, P. B. Mather, P. Prentis, Y. Li, B. Tang, and D. A. Hurwood, “Quantitative Genetic Assessment of Female Reproductive Traits in a Domesticated Pacific White Shrimp (Penaeus vannamei) Line in China," Sci. Rep., vol. 10, no. 1, p. 7840, Dec. 2020, doi: 10.1038/s41598-020-64597-x.

11. Indra, Safrida, E. Marsudi, and I. Zikri, "Analysis of production and input efficiency of tiger shrimp pond in Aceh Jaya district, Indonesia," IOP Conf. Ser. Earth Environ. Sci., vol. 425, p. 012059, Feb. 2020, doi: 10.1088/1755-1315/425/1/012059.

12. “https://www.aims.gov.au/reef-monitoring/gbr-condition-summary-2019-2020." .

13. M. Y. Dawed, P. R. Koya, and A. T. Goshu, "Mathematical Modelling of Population Growth: The Case of Logistic and Von Bertalanffy Models," Open J. Model. Simul., vol. 02, no. 04, pp. 113-126, 2014, doi: 10.4236/ojmsi.2014.24013.

14. P.S. S. Anand et al., "Growth performance of black tiger shrimp (Penaeus monodon) in substrate based zerowater exchange system," p. 10.

15. “Mantelatto, F. L. M., and L. R. Barbosa. 'Population structure and relative growth of freshwater prawn Macrobrachium brasiliense (Decapoda, Palaemonidae) from São Paulo State, Brazil.' Acta Limnologica Brasiliensia 17, no. 3 (2005): 245255." .

16. “Dall, W. H. B. J., B. J. Hill, Peter C. Rothlisberg, and D. J. Sharples. 'The biology of the Penaeidae.' The biology of the Penaeidae. 27 (1990)." .

17. R. Yu, P. Leung, and P. Bienfang, "Predicting shrimp growth: Artificial neural network versus nonlinear regression models," Aquac. Eng., vol. 34, no. 1, pp. 26-32, Jan. 2006, doi: 10.1016/j.aquaeng.2005.03.003.

18. A. Esmaeili and M. H. Tarazkar, "Prediction of shrimp growth using an artificial neural network and regression models," Aquac. Int., vol. 19, no. 4, pp. 705-713, Aug. 2011, doi: 10.1007/s10499-010-9386-8.

19. J. van Beijnen and G. Yan, “A practical guide to using AI in aquaculture," p. 9.

20. A. Rahman, J. Dabrowski, and J. McCulloch, "Dissolved oxygen prediction in prawn ponds from a group of one step predictors," Inf. Process. Agric., vol. 7, no. 2, pp. 307-317, Jun. 2020, doi: 10.1016/j.inpa.2019.08.002.

21. X. Yang, S. Zhang, J. Liu, Q. Gao, S. Dong, and C. Zhou, “Deep learning for smart fish farming: applications, opportunities and challenges," Rev. Aquac., vol. 13, no. 1, pp. 66-90, Jan. 2021, doi: 10.1111/raq.12464.

22. R. Abd. Rahman, G. Kendall, R. Ramli, Z. Jamari, and K. R. Ku-Mahamud, "Shrimp Feed Formulation via Evolutionary Algorithm with Power Heuristics for Handling Constraints," Complexity, vol. 2017, pp. 1-12, 2017, doi: $10.1155 / 2017 / 7053710$. 